\title{
The Influence of the Endurance Training with Costant and Variable Intensity on the Level of the Lactic Acid
}

\author{
Kacper Gotner, Piotr Sawicki and Marcin Dornowski* \\ DGdansk University of Physical Education and Sport \\ *Corresponding author: Marcin Dornowski, Gdansk University of Physical Education and Sport, Poland
}

\begin{tabular}{|c|c|}
\hline ARTICLE INFO & ABSTRACT \\
\hline Received: 亚 July 06, 2019 & Citation: Kacper Gotner, Piotr Sawicki, Marcin Dornowski. The Influence of the Endurance \\
\hline Published: 㗀 July 15, 2019 & $\begin{array}{l}\text { Training with Costant and Variable Intensity on the Level of the Lactic Acid. Biomed J Sci \& } \\
\text { Tech Res 19(4)-2019. BJSTR. MS.ID.003336. }\end{array}$ \\
\hline
\end{tabular}

\section{Introduction}

Prior to have been burnt in aerobic processes, every molecule of glucose undergoes the process of glycolysis consisting in the division of it into two molecules with three carbon bonds. Subsequently, those molecules undergo further transformation Dembińska Kieć et al. [1]. These processes require the presence of oxygen. When the organism is not able to supply oxygen in sufficient quantities, it begins to produce energy in the process of anaerobic glycolysis. As the product of this process the molecules of lactic acid are produced, the presence of which can be detected in the blood Yoshida et al. [2]. Anaerobic glycolysis takes places mainly in muscles, where the lactic acid produced in this process is transferred to the liver. In our study we have been checking the correlation of the changes in concentration of lactic acid molecules and the type of training exercises. The study of the type of exercises, and of the manner and quantities of the lactic acid molecules secreted allows for optimization of the type of training for particular person or a group of people Coco et al. [3]. In professional sport this allows for better planning of a training or training cycles Thibault et al. [4]. For people practicing sports recreationally this may be helpful in treating diabetes or insulin resistance, as during the training the molecules of glucose are being burnt.

\section{Material and Methods}

The level of lactic acid was being measured by piercing a fingertip and extraction of a drop of the blood of the tested person in his/her resting state and after the performing of the training, when Pundir et al. [5]. The testing group consisted of 13 physically active persons (students of The Academy of Physical Education and Sports) Riegler et al. [6,7], who were performing exactly the same training in their sex group. The group consisted of both women and men of age 21 to 24 . The training sessions were separated by 48 hour resting periods in which, to optimize the results of the test, the participants were not performing any other trainings.

\section{Experiment 1 (Constant Method - Variable Intensity)}

Variable work $400 \mathrm{~m}-200 \mathrm{~m}$

Work pace for $1 \mathrm{~km}$ : 5'20"'-men ; 5'40"-women

Work pace at the distance of 400m: 2'04'- men ; 2'10"- women. Work pace at the distance of $200 \mathrm{~m}: 1^{\prime} 12^{\prime \prime}$-men ; 1'20"- women.

Overall period of effort: 30 minutes.

\section{Experiment 1 (Constant Method-Steady Intensity)}

Constant work

Work pace for $1 \mathrm{~km}$ : 5'30" -men; 5' 45"'-women

Overall period of effort: 30 minutes

Statistical analysis were done using Statistical 12.

\section{Results}

The results of the tests show the increase of the level of lactic acid molecules in blood by 74,6\% during the training with the method of variable pace as compared to resting state (statistically significant). On the other hand, the results of the tests performed at the steady pace method showed $4,6 \%$ increase to the resting value. Our study shows the differences in reaction of the well-trained organisms to the training at varying intensity. It also shows when the high or low level of the lactic acid in blood may be expected and what is the level of its molecules in physically active persons during rest. This seems to be true especially in men, who occasionally show values 
higher than 3,0 during rest, while in women, usually having lesser muscle mass, the results seldom exceed 2,0. Particular individuals, probably better trained or simply better suited for the particular level of training show results differing from the rest of the group. However, these instances seem to be isolated. The final percent average in the tested group point to the principle of secretion of larger quantities of lactic acid to blood during the training with the constant method at variable pace, as opposed to the variable method at steady pace (Tables $1 \& 2$ ).

Table 1: The level of lactic acid after experiment one and two in women.

\begin{tabular}{|c|c|c|c|}
\hline No & Baseline (mmol/l) & Experiment 1 (mmol/l) & Experiment 2 (mmol/l) \\
\hline 1 & 1,29 & 4,99 & 3,99 \\
\hline 2 & 1,82 & 5,24 & 1,96 \\
\hline 3 & 1,18 & 2,13 & 1,27 \\
\hline 4 & 1,87 & 1,31 & 0,96 \\
\hline 5 & 1,70 & 1,27 & 1,76 \\
\hline 6 & 1,85 & 1,79 & 1,24 \\
\hline
\end{tabular}

Table 2: The level of lactic acid after experiment one and two in men.

\begin{tabular}{|c|c|c|c|}
\hline No & Baseline (mmol/l) & Experiment 1 (mmol/l) & Experiment 2 (mmol/l) \\
\hline 1 & 2,62 & 4,13 & 2,50 \\
\hline 2 & 3,19 & 3,48 & 2,05 \\
\hline 3 & 2,24 & 6,78 & 3,10 \\
\hline 4 & 3,27 & 7,45 & 1,64 \\
\hline 5 & 2,49 & 1,68 & 1,80 \\
\hline 6 & 2,29 & 6,08 & 2,95 \\
\hline 7 & 2,60 & 3,28 & 4,59 \\
\hline
\end{tabular}

\section{References}

1. Dembińska Kieć A, Naskalski JW (2009) Diagnostyka laboratoryjna z elementami biochemii klinicznej. Urban \& Partner, Wrocław.

2. Zhang Y, Yoshida M, Vadlani PV (2018) Biosynthesis of D-lactic acid from lignocellulosic biomass. Microbiol Biotechnol 40(8): 1167-1179.

3. Coco M, Di Corrado D, Ramaci T, Di Nuovo S, Perciavalle V, et al. (2019) A Role of lactic acid on cognitive functions. Phys Sportsmed 7:1-7

4. Guy Thibault, François Pérnott (2006) It is not lactic acid's fault.

\section{ISSN: 2574-1241}

DOI: 10.26717/BJSTR.2019.19.003336

Marcin Dornowski. Biomed J Sci \& Tech Res

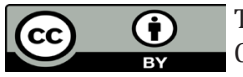

This work is licensed under Creative Commons Attribution 4.0 License

Submission Link: https://biomedres.us/submit-manuscript.php
5. Pundir CS, Narwal V, Batra B (2016) Determination of lactic acid with special emphasis on biosensing methods: A review. Biosens Bioelectron 86: 777-790.

6. Riegler M, Stotz G, Fitzgerald K, Munoz CK, Lewis J, et al. (2017) Acute Responses to the 7-Minute Workout. J Strength Cond Res 31(9): 25722578.

7. Darwin, Wipa Charles, Cord Ruwisch R (2018) Concurrent Lactic and Volatile Fatty Acid Analysis of Microbial Fermentation Samples by Gas Chromatography with Heat Pre-treatment. Journal of Chromatographic Science 56(1): 1-5.

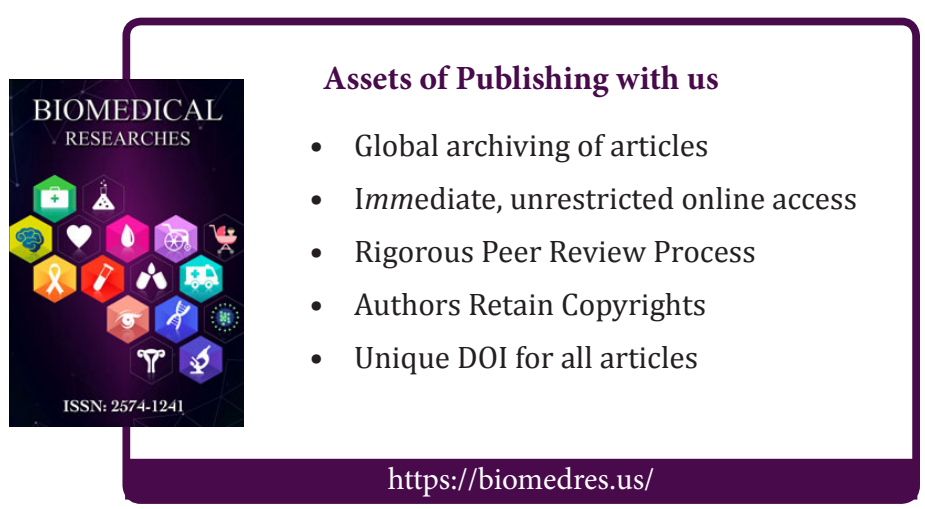

